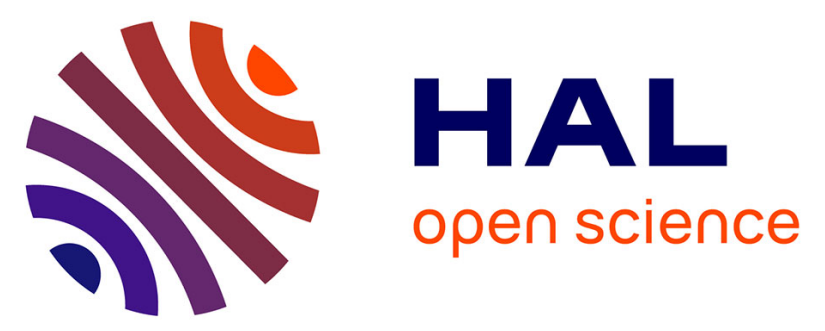

\title{
Capture-recapture abundance and survival estimates of three cetacean species in Icelandic coastal waters using trained scientist-volunteers
}

Chiara G Bertulli, Loreleï Guéry, Niall Mcginty, Ailie Suzuki, Naomi Brannan, Tania Marques, Marianne H Rasmussen, Olivier Gimenez

\section{To cite this version:}

Chiara G Bertulli, Loreleï Guéry, Niall Mcginty, Ailie Suzuki, Naomi Brannan, et al.. Capturerecapture abundance and survival estimates of three cetacean species in Icelandic coastal waters using trained scientist-volunteers. Journal of Sea Research (JSR), 2017, 131, pp.22 - 31. 10.1016/j.seares.2017.10.001 . hal-03499285

\section{HAL Id: hal-03499285 \\ https://hal.science/hal-03499285}

Submitted on 25 Dec 2021

HAL is a multi-disciplinary open access archive for the deposit and dissemination of scientific research documents, whether they are published or not. The documents may come from teaching and research institutions in France or abroad, or from public or private research centers.
L'archive ouverte pluridisciplinaire HAL, est destinée au dépôt et à la diffusion de documents scientifiques de niveau recherche, publiés ou non, émanant des établissements d'enseignement et de recherche français ou étrangers, des laboratoires publics ou privés. 


\section{Accepted Manuscript}

Capture-recapture abundance and survival estimates of three

cetacean species in Icelandic coastal waters using trained scientist-volunteers

Chiara G. Bertulli, Loreleï Guéry, Niall McGinty, Ailie Suzuki, Naomi Brannan, Tania Marques, Marianne H. Rasmussen, Olivier Gimenez

PII:

DOI:

Reference:

To appear in:

Received date:

Revised date:

Accepted date:
S1385-1101(16)30362-8

doi:10.1016/j.seares.2017.10.001

SEARES 1602

Journal of Sea Research

22 December 2016

25 August 2017

2 October 2017

Please cite this article as: Chiara G. Bertulli, Loreleï Guéry, Niall McGinty, Ailie Suzuki, Naomi Brannan, Tania Marques, Marianne H. Rasmussen, Olivier Gimenez, Capturerecapture abundance and survival estimates of three cetacean species in Icelandic coastal waters using trained scientist-volunteers. The address for the corresponding author was captured as affiliation for all authors. Please check if appropriate. Seares(2017), doi:10.1016/j.seares.2017.10.001

This is a PDF file of an unedited manuscript that has been accepted for publication. As a service to our customers we are providing this early version of the manuscript. The manuscript will undergo copyediting, typesetting, and review of the resulting proof before it is published in its final form. Please note that during the production process errors may be discovered which could affect the content, and all legal disclaimers that apply to the journal pertain. 


\section{Capture-recapture abundance and survival estimates of three cetacean species in Icelandic coastal waters using trained scientist-volunteers}

Chiara G. Bertulli, ${ }^{1, *}$, Loreleï Guéry ${ }^{2,3}$, Niall McGinty ${ }^{4}$, Ailie Suzuki, Naomi Brannan ${ }^{5}$, Tania Marques $^{4}$, Marianne H. Rasmussen ${ }^{5}$, Olivier Gimenez ${ }^{3}$

${ }^{1}$ Department of Life and Environmental Sciences, University of Iceland, Sturlugata 7, 101 Reykjavik, Iceland; Email: chiara.bertulli@ gmail.com ("Corresponding author)

${ }^{2}$ Département de Biologie, Chimie et Géographie, Université du Québec à Rimouski, 300 allée des Ursulines, G5L 3A1, Rimouski, Québec, Canada ; Email: lorelei.guery@ gmail.com

${ }^{3}$ CEFE UMR 5175, CNRS, Université de Montpellier, Université Paul-Valéry Montpellier, EPHE, 1919 Route de Mende, 34293 Montpellier Cedex 5, France ; Email: olivier.gimenez@ cefe.cnrs.fr

${ }^{4}$ Marine Macroecology and Biogeochemistry Lab, Mount Allison University, Sackville, New Brunswick, Canada ; Email : nmcginty@mta.ca

${ }^{5}$ Húsavik Research Centre, University of Iceland, Hafnarstétt, 640 Húsavik, Iceland; Ailie Suzuki Email: ailie.suzuki@ gmail.com; Naomi Brannan - Email: naomibrannan@ hotmail.com; Tania Marques - Email: taniarsmarques@gmail.com; Marianne H. Rasmussen - Email: mhr@hi.is 


\section{Abstract}

Knowledge of abundance and survival of humpback whales, white-beaked dolphins and minke whales are essential to manage and conserve these species in Icelandic coastal shelf waters. Our main goal was to test the feasibility of employing inexpensive research methods (data collected by trained-scientist volunteers onboard opportunistic vessels) to assess abundance and apparent survival. No previous studies in Iceland have investigated these two demographic parameters in these three cetacean species using open capture-recapture models accounting for imperfect and possibly heterogeneous detection. A transient effect was accounted for whenever required to estimate the population of resident individuals. Identification photographs were collected by scientist-trained volunteers for 7 years (2006-2013) from onboard commercial whale-watching vessels in the coastal waters of Faxaflói (southwest coast, $\sim 4,400 \mathrm{~km}^{2}$ ) and Skjálfandi (northeast coast, $\sim 1,100 \mathrm{~km}^{2}$ ), Iceland. We estimated an average abundance of 83 humpback whales (Mn; 95\% confidence interval: 54-130) in Skjálfandi; 238 white-beaked dolphins (La; [163-321]) in Faxaflói; and 67 minke whales (Ba; [53-82]) in Faxaflói and 24 (14-31) in Skjálfandi. We also found that apparent survival was constant for all three species (Mn: 0.52 [0.41-0.63], La: 0.79 [0.64-0.88], Ba-Faxaflói: 0.80 [0.67-0.88], Ba-Skjálfandi: 0.96 [0.60-0.99]). Our results showed inter-annual variation in abundance estimates which were small for all species, and the presence of transience for minke whales. A significant increase in abundance during the study period was solely found in minke whale data from Skjálfandi. Humpback whales and white-beaked dolphins showed lower apparent survival rates compared to similar baleen whale and dolphin populations. Our results show data collected by trained-scientist volunteers can produce viable estimates of abundance and survival although bias in the methods we employed exist and need to be addressed. With the continued increase in anthropogenic pressures on our three target populations in these regions our results can be used by relevant stakeholders to develop appropriate conservation strategies in the region. 
Keywords: Abundance, survival, capture-recapture, volunteers, minke whale, white-beaked dolphins, humpback whale, Iceland 


\section{Introduction}

For management and conservation purposes, it is crucial to gather information about abundance, survival, movement and distribution of free-ranging cetacean populations (Silva et al., 2009; Dick et al., 2011). As it has been suggested in other studies (e.g. Parra et al., 2006; Papale et al., 2016), estimates of abundance and survival as well as existing information on movement patterns can be also used to start managing all sources of anthropogenic pressure cetacean species confront. To obtain these estimates it is paramount that a large amount of data is collected across many years, which can be costly (Kaufmann et al., 2011; New et al., 2015). Several research projects monitoring cetaceans around the world have opted for citizen science as an inexpensive way to collect and analyze data relying on the help of 'non-scientific members' (Silvertown, 2009) of the general public, or 'non-specialist volunteers' (Bruce et al., 2014). For cetacean research, citizen science has been used in several studies investigating occurrence, habitat use (Bristow et al., 2001), abundance and distribution (Bruce et al., 2014), with data collected from land or from boats, either research or opportunistic. Data have also been collected by 'experienced volunteers' (Newman et al, 2003) and 'trained scientists' (Higby et al., 2012) who both have a scientific background and to whom training is provided, which were both found to reduce bias during data collection and analysis (summarized in Thiel et al., 2014). Volunteers are asked to photograph animals using the photo-identification technique (Würsig \& Würsig, 1977) and the photos are processed in order to get individual resightings using natural markings. These data are then analysed using standard capture-recapture (CR) methods to estimate abundance and demographic parameters.

Minke (Balaenoptera acutorostrata) and humpback whales (Megaptera novaeangliae) are commonly sighted in Icelandic waters from March to November and occasionally in the winter (Bertulli et al., 2013; Magnúsdóttir et al., 2014) while white-beaked dolphins (Lagenorhynchus albirostris) occur all year long (Víkingsson \& Ólafsdóttir, 2004). Previous studies also revealed that 
all species display site fidelity, although the majority of individuals are highly mobile, sighted only once, and spend part of their time travelling outside of our study areas (Bertulli et al., 2013, 2015). Using aerial surveys conducted during the month of July and covering coastal waters $\leq 600 \mathrm{~m}$ (Gunnlaugsson et al., 1988), the abundance of minke whales was estimated to be 43,633 (95\% confidence interval [CI]: $30,148-63,149)$ in $2001,18,262(7,381-24,919)$ in 2007 , and 9,588 (5,274-14,420) in 2009 using cue-counting procedures (Pike et al., 2009, 2011; Borchers et al, 2009). The only abundance estimate for white-beaked dolphins in Icelandic waters using aerial line transect methods dates back to 2001 (North Atlantic Sighting Surveys conducted from 1986-2001), resulting in an estimated 31,653 animals (17,679-56,672) (Pike et al., 2009) although a small number of other dolphin species may be included in this count. Additionally, in $20014,928(1,926-$ 12,611) humpback whales were estimated (Pike et al., 2009) with 586 individuals recorded in the coastal waters of the northeast shelf that includes Skjálfandi (Block 4, 175 - 1,956). In Icelandic waters, humpback whales, white-beaked dolphins and minke whales are also subject to various pressures related to whale-watching (Christiansen et al., 2015), fishery (Vikingsson \& Ólafsdóttir, 2004; Basran, 2014), whaling activities (Marine Research Institute, 2014) as well as changes in the marine coastal environment (V1kingsson et al., 2015), all of which have been reported in both our study areas (see Discussion below).

Previous studies have shown that photo-identification is a suitable method to identify our three Icelandic cetacean species (Bertulli et al., 2013; 2015), but to date no other studies presenting abundance and survival estimates using CR methods and trained-scientists volunteers exist for this area. We wish to address these knowledge gaps by answering the following questions: (1) Can data collected by trained-scientist volunteers onboard opportunistic vessels be used to estimate cetacean abundance and survival? (2) How do our estimates of apparent survival compare with those of humpback whale, white-beaked dolphin and minke whale found outside of Iceland? 3) What is the short term stability of the three Icelandic populations? 4) Do these populations show any evidence of 'transience'? (i.e. 'transience' occurs when whales are traversing an area only once with no 
further chances to be encountered or sighted again (Pradel et al., 1997) This is the first study presenting capture-recapture abundance and survival estimates of humpback whales, white-beaked dolphins and minke whales from Iceland, using data collected by trained-scientist volunteers onboard opportunistic vessels. Our goal here was to study the feasibility of capture-recapture abundance and survival estimation using a new inexpensive method involving these volunteers.

\section{Material and Methods}

\subsection{Study area}

The study areas including the coastal waters of Faxaflói $\left(64^{\circ} 24^{\prime} \mathrm{N}, 22^{\circ} 00^{\prime} \mathrm{W} ; \sim 4,400 \mathrm{~km}^{2}\right)$ and Skjálfandi $\left(66^{\circ} 05^{\prime} \mathrm{N}, 17^{\circ} 33^{\prime} \mathrm{W} ; \sim 1,100 \mathrm{~km}^{2}\right)$ have been previously described by Bertulli et al. (2012). Both bays are approximately $600 \mathrm{~km}$ apart and located in the southwest and northeast of Iceland, respectively (Fig. 1).

\subsection{Sampling methods}

From 2006 to 2013, non-systematic and opportunistic boat surveys were conducted onboard motor whale-watching vessels (20-26 m in length) in sea state of zero to three on the Beaufort scale. Each boat survey lasted approximately 3 hours and covered morning, afternoon or evening hours due to the high latitude of the study sites. When possible, vessels would run parallel to whales and dolphin groups, allowing researchers to systematically shoot the entire surfacing pattern of each randomly encountered individual, with no preference given to marked animals over unmarked animals. 
a)

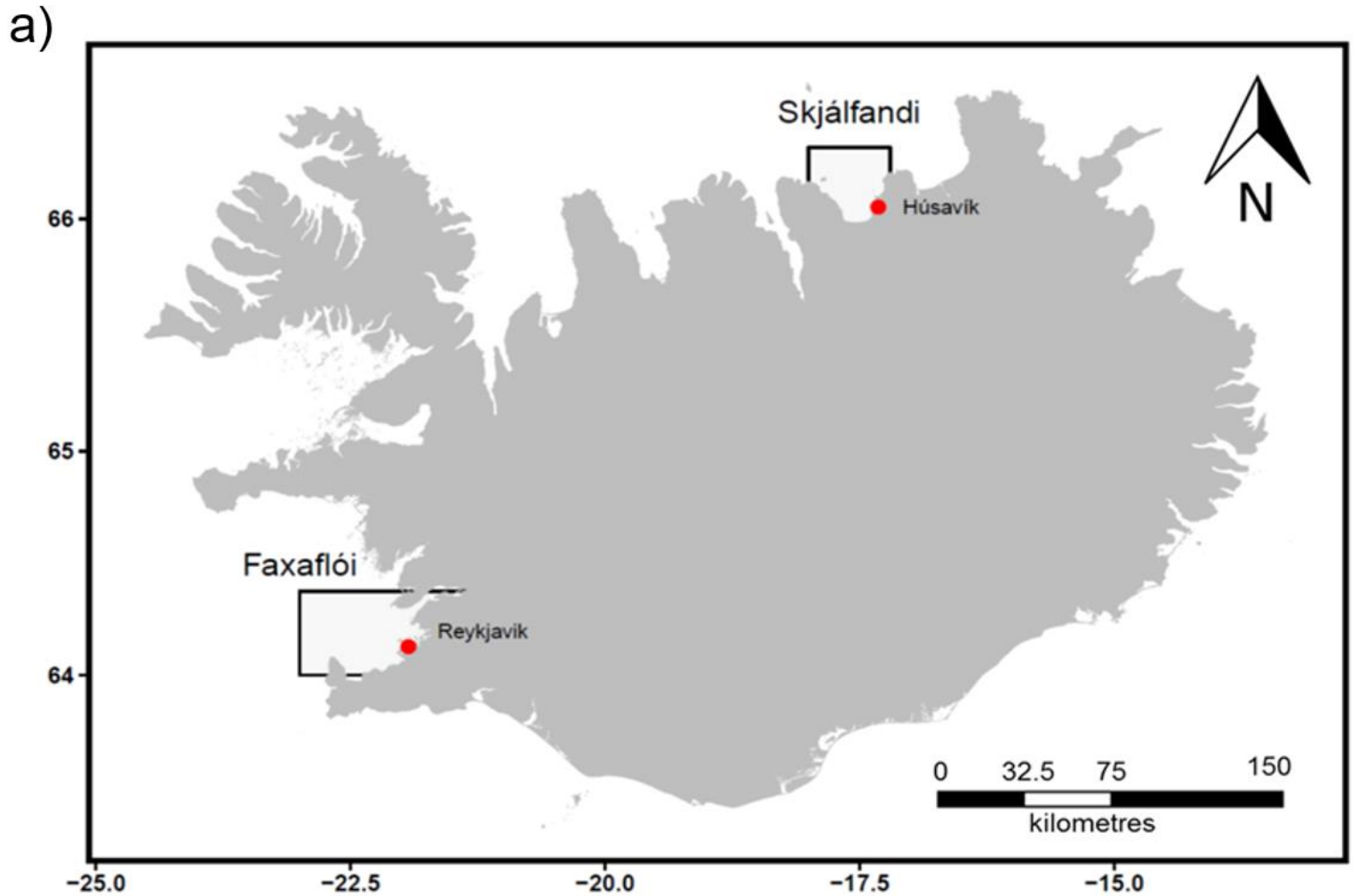

b)

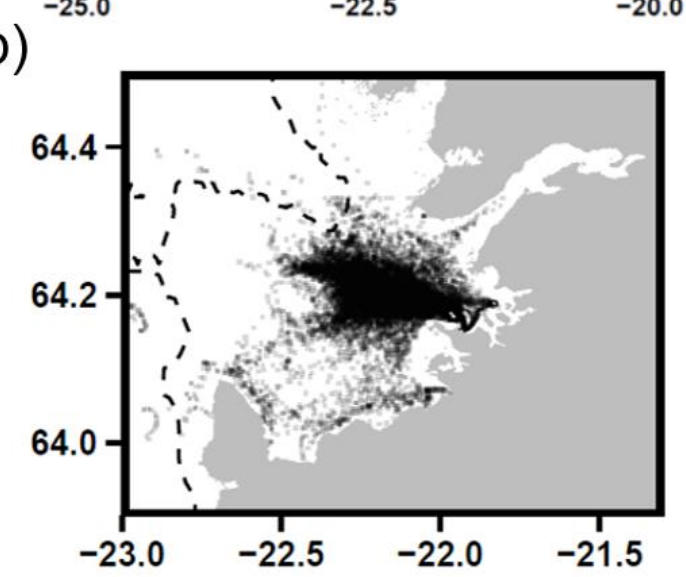

c)

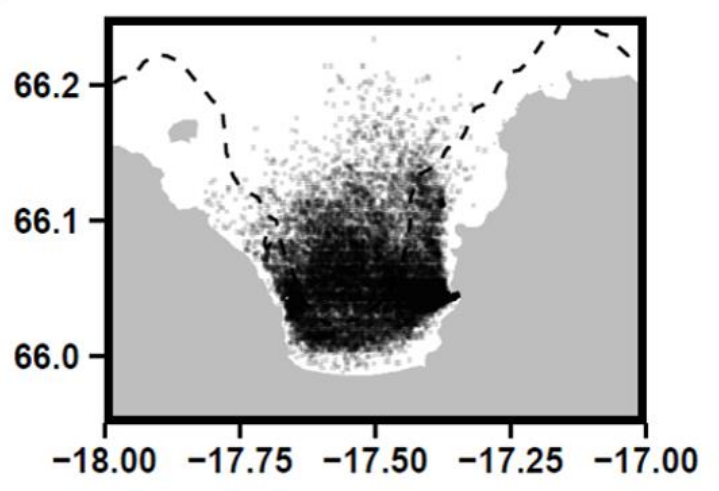

Figure 1. Map of the study area showing Faxaflói (b) and Skjálfandi (c), Iceland. Sub-panels show the density of observations made within the two areas; surveys were conducted within light grey areas.

\subsection{Photo-identification}

One to a maximum of four observers, usually the principle investigator and three scientist volunteers, were part of the photo-identification team onboard survey vessels in Faxaflói and Skjalfandi. Volunteers underwent a selection process, and individuals with scientific background, 
preferably with previous cetacean research and good photographic skills were chosen. Training was provided by the principal investigator (CGB or MHR) on board, to teach scientist volunteers individually how to collect photo-id images. Volunteers were also followed in data entry and given lectures and materials (e.g. publications, reports) on studied species and field techniques used. A range of DSLR cameras was used in both study areas, with zoom lenses ranging from 55-200mm to 70-300 mm for Faxaflói and 28-135 mm to 40-150 mm for Skjálfandi. Images were taken in both JPG (300 pixel/inch) and RAW formats.

A grading system of quality (Q1-Q6; Figure 1 in Gowans \& Whitehead, 2001; Figure 1 in Rosso et al., 2011) and distinctiveness (D1-D4; Table 1 in Zaeschmar et al., 2014) was used to evaluate photographs. Images rated $\mathrm{Q} \geq 5$ of adult only, and with 'distinctive' and 'very distinctive' fins were considered suitable for the analysis (Gowans \& Whitehead, 2001, Zaeschmar et al, 2014). Adults were defined based on the estimated body length of each individual and their behaviour towards conspecifics (humpback whale: length at maturity of 11.6-12 m, V1kingsson, 2004b; whitebeaked dolphin: 2.6-2.8 m, Vikingsson \& Ólafsdóttir, 2004; minke whale: 6.5-7.5 m, Vikingsson, 2004a). In order to avoid misidentifications (e.g. false negatives) with minke whales and whitebeaked dolphins, dorsal fin outline marks and injury marks were used as the only primary features as they were found to be both stable and long-lasting identification marks for each species (Bertulli et al., 2016). Linear marks for white-beaked dolphins and bite marks for minke whales were used as secondary features, since they were found to be reliable marks for recaptures spanning 5 and 8 years respectively (Bertulli et al., 2016). Humpback whales were primarily identified using pigmentation patterns on the ventral side of their flukes (Katona et al., 1979) and the presence of notches in the dorsal fin edge, and injury marks on flukes, flanks, and/ or dorsal fin as secondary features. Photoid images were matched in chronological order of collection to detect any change of outline and body marks over time. Using the 2008-2013 data sets, proportions of identifiable individuals per group were calculated to estimate coverage. 


\subsection{Capture-recapture analysis}

We used the year as a time unit utilizing 2008-2013 for white-beaked dolphins and minke whales in Faxaflói, 2006-2013 in Skjálfandi for humpback whales and 2008-2013 for minke whales. Each year was made of 5 months in each bay (April to August in Faxaflói, May to September in Skjálfandi; see Table 1 for total number of days and associated sighting frequency for each species), which for each species corresponded to the period with the highest number of captures (e.g. Alves et al., 2014). By doing so, an occasion (a year made of a 5-month period) was relatively short compared to the interval between occasions, which however made it impossible to define secondary occasions and therefore to apply the Pollock's closed robust design (Pollock, 1982) for the analysis. Because mortality could occur over the study period, we resorted to Cormack-Jolly-Seber (CJS) open-population models (Lebreton et al., 1992) to estimate abundance while accounting for apparent survival (the product of true survival and fidelity, hereafter as 'survival'); $\phi$ ) and the recapture ( $p$ ) probabilities that may be less than 1 . We considered constant or time dependent effects on these parameters, resulting in four different models: (1) both $\phi$ and $p$ constant over time; (2) $\phi$ constant and $p$ time-dependent; (3) $\phi$ time-dependent and $p$ constant; and (4) both $\phi$ and $p$ time-dependent.

RMark (Laake, 2013) was used for model fitting, U-CARE (Choquet et al., 2009) for assessing model quality of fit (Pradel et al., 2005). Regarding the latter, a P value $>0.05$ would mean that the null hypothesis 'the CJS model fits the data well' cannot be rejected. While trapdependence was not detected for any of the three species, we detected a transient effect for both populations of minke whales (see Results), which was incorporated following Pradel et al. (1997) by using a two-age class for survival. Individuals that were sighted only once were part of the first age-class (transients were included in this class) while all the others were part of the second. The age in CR analysis was considered as the time passed since the animal was first sighted (Ramp et al., 2006; Madon et al., 2012). The proportion of transients was estimated and the abundance estimate amended accordingly (Madon et al., 2012). To test and account for the presence of 
heterogeneity in the detection process, we used CR mixture models (Pledger et al., 2010) in which animals belong to different classes of detection in proportions to be estimated. To determine the most parsimonious model, the model with the lowest AICc score (Akaike Information Criterion corrected for small sample sizes; Burnham \& Anderson, 2002) was selected. The selected model was then used in a bootstrap procedure (with 500 iterations) to calculate $95 \%$ confidence interval for population size (Cubaynes et al, 2010). The $\mathrm{R}$ code is available from GitHub at https:/github.com/oliviergimenez/abundance_estimation. To assess trends in abundance, we performed weighted linear regressions of the estimated parameters over time, using the inverse of the squared bootstrapped standard deviation as the model weight. For minke whales, data from both Faxaflói and Skjálfandi were used, and each bay was considered separately to calculate abundance. Two minke whales (DEM72 sighted 2 times, DEM217 sighted 7 times) were resighted between bays but they were only considered as part of the Faxaflói population, as they were sighted more often there. Due to the low number of exchanges between bays made by these two whales, no movement probabilities could be estimated (Lebreton et al., 2009). For white-beaked dolphins, only data from Faxaflói were used, because only three individual dolphins were resighted in the other bay. For humpback whales, only data from Skjálfandi were used, because only five individuals were resighted in Faxaflói.

Histograms of capture frequencies were produced to show how much heterogeneity was present in the data. Humpback whales, white-beaked dolphins and minke whales were allocated to one of four categories by estimating the number of times they were recaptured: (1) 'common' $\geq 12$ times; 'frequent' 8-11 times; 'occasional' 4-7 times; and 'rare' $\leq 3$ times (Culloch, 2004).

\subsection{Open capture-recapture models}

To avoid introducing bias in estimates of abundance, survival and recapture probability using capture-recapture methods, it is vital that model assumptions are met. In this study, open model (CJS) assumptions (Hammond, 1986; Lebreton et al., 1992) were the following (see also 
paragraph 4.1.1 in Discussion): (1) natural marks carried by whales and dolphins during this study should not be lost or missed, (2) natural marks carried by all individuals should be accurately recognized during recaptures, (3) individuals should be released quickly after being captured, (4) sampling sessions should be of shorter duration compared to total duration of the sampling period, (5) all alive marked whales and dolphins available on each sampling occasion should have equal capture probabilities, (6) and survival probabilities. Permanent emigration (e.g. population increases or decreases) are allowed in open population models differently from closed one (Lebreton et al, 1992; Williams et al., 2002).

The first open-model population assumption states that natural marks carried by whales and dolphins during this study should not be lost or missed. To validate this assumption, strict quality controls were adopted during data analysis, and the only photo-ID images used to identify whales and dolphins were of very high quality $(\mathrm{Q} \geq 5)$ and of distinctive fins (D1-D2). Additionally, the only natural marks used to identify individuals were those with low loss and gain rates, as stable marks do not allow for misidentifications (e.g. Urian et al., 2015). Bias in abundance estimates produced in this study might be present due to the choice to discard unmarked individuals. Photo-id images were limited to individuals with distinctive fins or flukes so abundance estimates pertain to the number of residents with distinctive marks and consequently our numbers are likely underestimating the true measure for each species. Our current estimates were also not produced using images of individuals with no marks or short-lasting marks into account, so including them in future analysis might help to contextualize our current results.

The second assumption suggests that natural marks carried by all individuals should be accurately recognized during recaptures. To validate this assumption and minimize human errors in matching dorsal fins and flukes over the years, regular checks were conducted only by the most experience researchers (CGB or MHR; e.g. Urian et al., 2015, Santostasi et al., 2016). 
The third assumption states that individuals should be released quickly after being captured. Animals were not physically removed during each photographic session but simply captured in a photo-identification image (e.g. Silva et al., 2009). The time spent photographing whales and dolphins was much shorter in duration compared to the time spent searching for animals in between photographic sessions, so this assumption was respected.

The fourth assumption (e.g. sampling sessions are of shorter duration compared to total duration of the sampling period) was also met having sampling occasions of 5 months, of much shorter duration compared to the interval between occasions (7 months).

To verify the fifth and sixth assumptions (e.g. all alive marked whales and dolphins available on each sampling occasion should have equal capture probabilities, and survival probabilities) were met, trap-dependence and transience were tested. Transience was accounted for while estimating abundance and survival using a two-age class on survival (Pradel et al., 1997). Equal recapture probabilities were partially met (and trap-dependence was not significant), because mixing between sampling periods occurred, with individuals in all our three populations observed leaving our study areas for some time to then return sometime later. However, movements outside of our bays show that some individuals have home ranges that extended beyond areas of our survey effort (e.g., Gilroy et al., 2012), making them unavailable for capture during this study. Presence of heterogeneity in the detection process could introduce bias but it was dealt with the use of CR mixture models (see Material and Methods). The assumption of equal survival probability was not likely achieved in this study because commercially hunting (of minke whales) and illegal (of whitebeaked dolphins) hunting occurring in Icelandic coastal shelf waters. 
Table 1. Annual effort spent for each species $(\mathrm{MW}=$ minke whale, $\mathrm{WBD}=$ white-beaked dolphin, HW = humpback whale $)$ in each site $(\mathrm{F}=$ Faxaflói, $\mathrm{S}=$ Skjálfandi) from 2008 (2006 for humpback whale) to 2013 .

\begin{tabular}{llllllllll}
\hline $\begin{array}{l}\text { Species- } \\
\text { Site }\end{array}$ & 2006 & 2007 & 2008 & 2009 & 2010 & 2011 & 2012 & 2013 & Total \\
\end{tabular}

\section{HW-S}

$\begin{array}{cccccccccc} & 11 & 02 & 12 & 02 & 17 \text { May } & 06 \text { May } & 02 \text { May } & 03 & \\ & \text { May } & \text { May } & \text { May } & \text { May } & - & - & - & \text { May- } & \\ \text { Capture } & - & - & - & - & & & & \\ \text { occasion } & & & & & 29 \text { Sept } & 06 \text { Sept } & 30 \text { Sept } & 29 & \\ & 03 & 19 & 15 & 20 & & & & \text { Sept } & \\ & \text { Sept } & \text { Sept } & \text { Sept } & \text { Sept } & & & & & \\ \text { Days } & 62 & 77 & 52 & 56 & 23 & 59 & 100 & 114 & 543 \\ \text { Trips } & 67 & 77 & 57 & 65 & 30 & 99 & 121 & 201 & 717 \\ \text { Sightings } & 126 & 112 & 87 & 117 & 34 & 134 & 369 & 613 & 1592 \\ \text { Obs. } & 58 & 56 & 41 & 47 & 17 & 75 & 95 & 163 & 552 \\ \text { time } & & & & & & & & & \end{array}$

\section{WBD-F}

Capture

occasion

$\begin{array}{ccc}\text { Days } & - & - \\ \text { Trips } & - & - \\ \text { Sightings } & - & -\end{array}$

Obs.

time

\section{MW-F}

Capture

occasion

$$
21 \quad 14 \quad 07 \mathrm{Apr} \quad 02 \mathrm{Apr} \quad 01 \mathrm{Apr} \quad 01 \mathrm{Apr}
$$

$$
\text { Apr - Apr }-
$$

$\begin{array}{llll}25 & 19 \quad 30 \mathrm{Aug} \quad 31 \mathrm{Aug} \quad 30 \mathrm{Aug} \quad 28\end{array}$

Aug Aug

$$
65 \quad 21
$$

17

$$
17
$$

23

33

176

$82 \quad 59$

52

48

55

59

355

$48 \quad 26$

19

20

29

42

184

24

19

12

13

\begin{tabular}{|c|c|c|c|c|c|c|c|c|}
\hline \multirow{4}{*}{$\begin{array}{l}\text { Capture } \\
\text { occasion }\end{array}$} & - & - & 21 & 14 & $07 \mathrm{Apr}$ & $02 \mathrm{Apr}$ & $1 \mathrm{Apr}-$ & $01 \mathrm{Apr}$ \\
\hline & & & Apr - & Apr - & - & - & \multirow{3}{*}{30 Aug } & - \\
\hline & & & 25 & 19 & 30 Aug & 31 Aug & & 28 \\
\hline & & & Aug & Aug & & & & Aug \\
\hline Days & - & - & 57 & 78 & 75 & 75 & 109 & 87 \\
\hline
\end{tabular}

19

33

120 


$\begin{array}{lccccccccc}\text { Trips } & - & - & 144 & 157 & 145 & 159 & 153 & 139 & 897 \\ \text { Sightings } & - & - & 317 & 384 & 289 & 405 & 481 & 307 & 2183 \\ \begin{array}{l}\text { Obs. } \\ \text { time }\end{array} & - & - & 96 & 69 & 94 & 142 & 139 & 93 & 633 \\ \text { MW-S } & & & & & & & & & \\ \\ \end{array}$




\section{Results}

\subsection{Humpback whales}

A cumulative number of 195 individual adult humpback whales were photo-identified between 2006 and 2013 (Fig. 2) in Skjálfandi, with 78\% (n = 153) of individuals photographed more than once and 26\% $(n=51)$ photographed across multiple years. A total of 1354 humpback whale groups (2006-2007 groups were not included in these calculations because data were not available) were encountered. Photographs quality rated Q5 or higher of 195 individuals were taken for $63 \%(n=859)$ of these groups. A total of $96 \%(n=826)$ of these groups had $50 \%$ or more individuals identified within each group. The recapture frequencies of the 195 marked humpback whales ranged from 1 to 61 with a median of 4 recaptures and an interquartile range (IQR) between 2 and 8 (Fig. 3). Following Culloch (2004), 48\% of identified individuals were 'rare' $(\mathrm{n}=93), 28 \%$ ( $n=55)$ were 'common' to 'frequent', and $24 \%$ were 'occasional' $(n=47)$. In Skjálfandi we found an appropriate fit of the CJS model to the data $\left(\chi^{2}=14.0\right.$, df $\left.=18, P=0.73\right)$. The best model retained constant survival and time-dependent recapture probability ( $2_{\mathrm{HW}}$, Table 2$)$. Models assuming homogeneity in the detection process were uniformly better supported than their heterogeneous counterpart (Table 2). The estimated constant survival was $0.52(0.41-0.63, \mathrm{SE}=$ 0.06). The highest detection probability was recorded in $2013(0.83, \mathrm{SE}=0.17)$ and the lowest in 2008 (0.15, SE = 0.10), with an average estimate of 0.52 ( $\mathrm{SE}=0.06$, Fig. 4). On average, we estimated a total abundance of 83 humpback whales in Skjálfandi (54-130). The annual abundance varied from 35 whales in 2007 (95\% CI: $17-65$, SD = 8) to 134 in 2012 (95\% CI: 80-267, SD = 29, Fig. 5a). There was no significant trend in the abundance estimates during this time. 


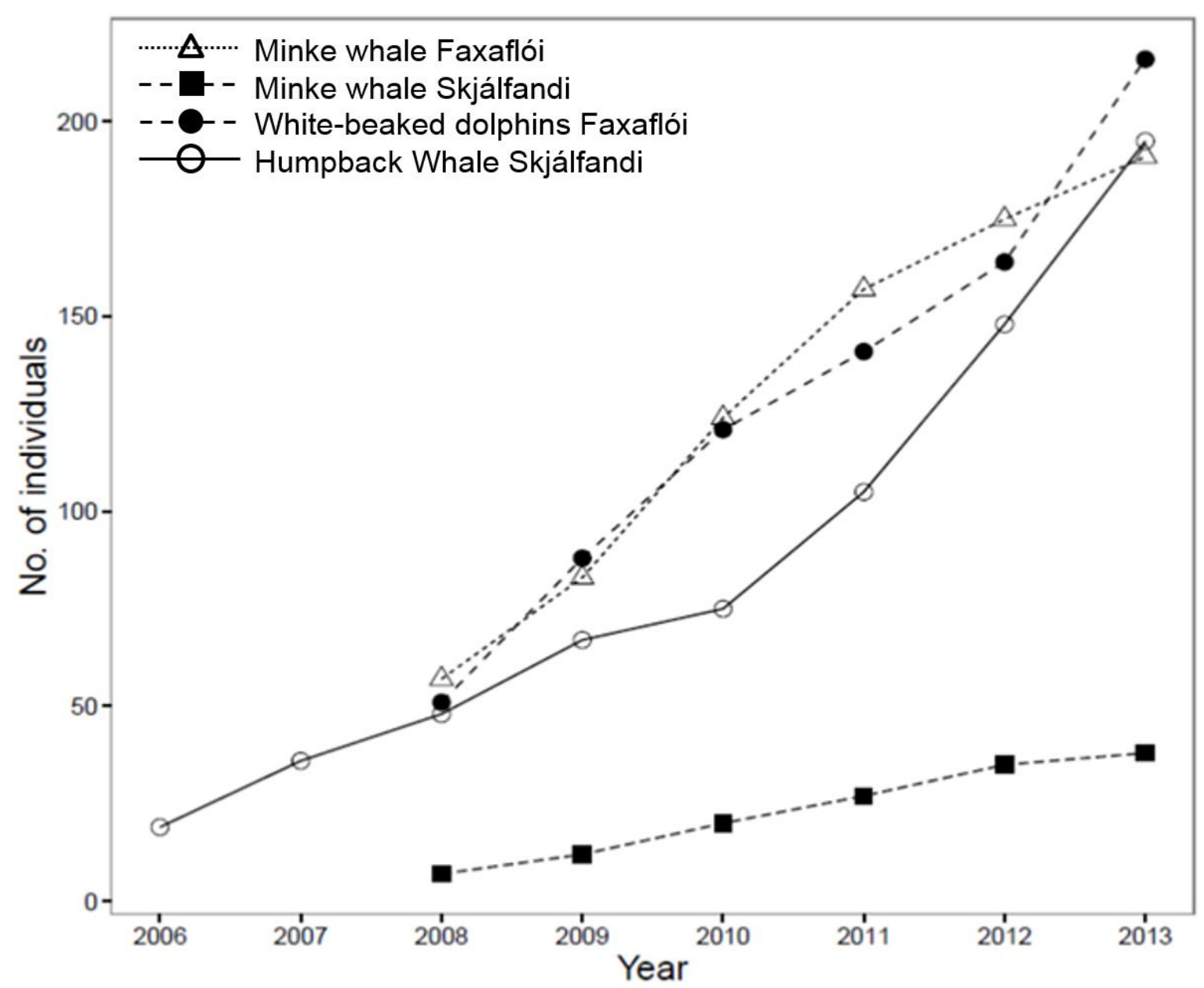

Figure 2. Summary of discovery curves (cumulative number of newly identified and catalogued whales and dolphins each year) of marked adult (a) humpback whales from Skjálfandi (continuous line with empty circles), (b) white-beaked dolphins from Faxaflói (dotted line with full circles) and (c) minke whales from both bays (dotted line with empty triangles for Faxaflói; dashed line with full squared for Skjálfandi), in each year (2006-2013). 


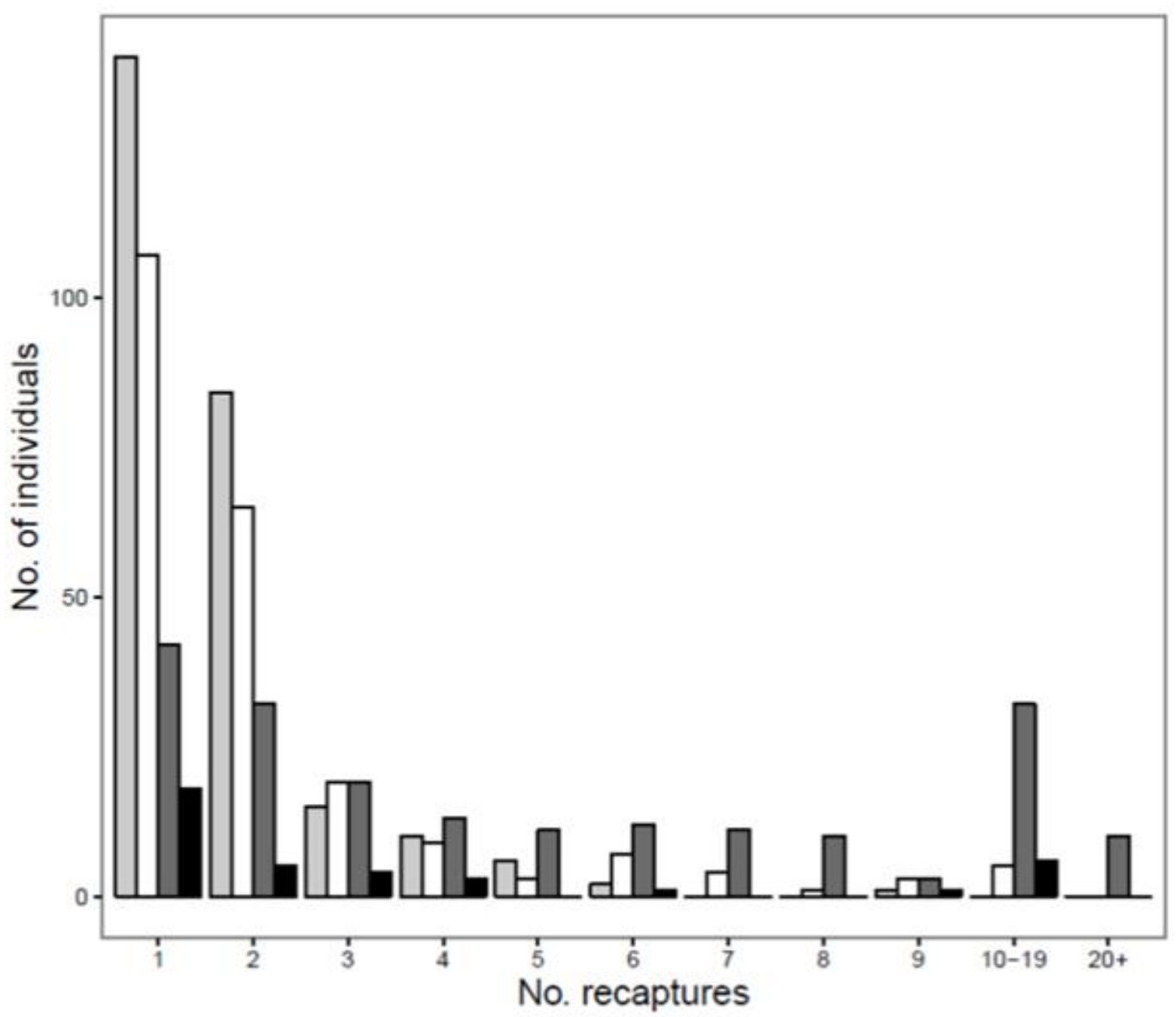

Figure 3. Distribution of capture frequencies of all identified (i) humpback whales in Skjálfandi (dark grey), (ii) white-beaked dolphins in Faxaflói (light grey), (iii) minke whales in Faxaflói (white), and (iv) Skjálfandi (black). 
Table 2. AICc scores for the four models (1-4) for each species. $\mathrm{AIC}_{\mathrm{c}}(1)$ without heterogeneity, $\mathrm{AIC}_{\mathrm{c}}(2)$ with heterogeneity. $\mathrm{HW}=$ humpback whale, $\mathrm{MF}=$ minke whale, Faxaflói, $\mathrm{MS}=$ minke whale, Skjálfandi, WBD = white-beaked dolphin. The best model for each species is in bold font.

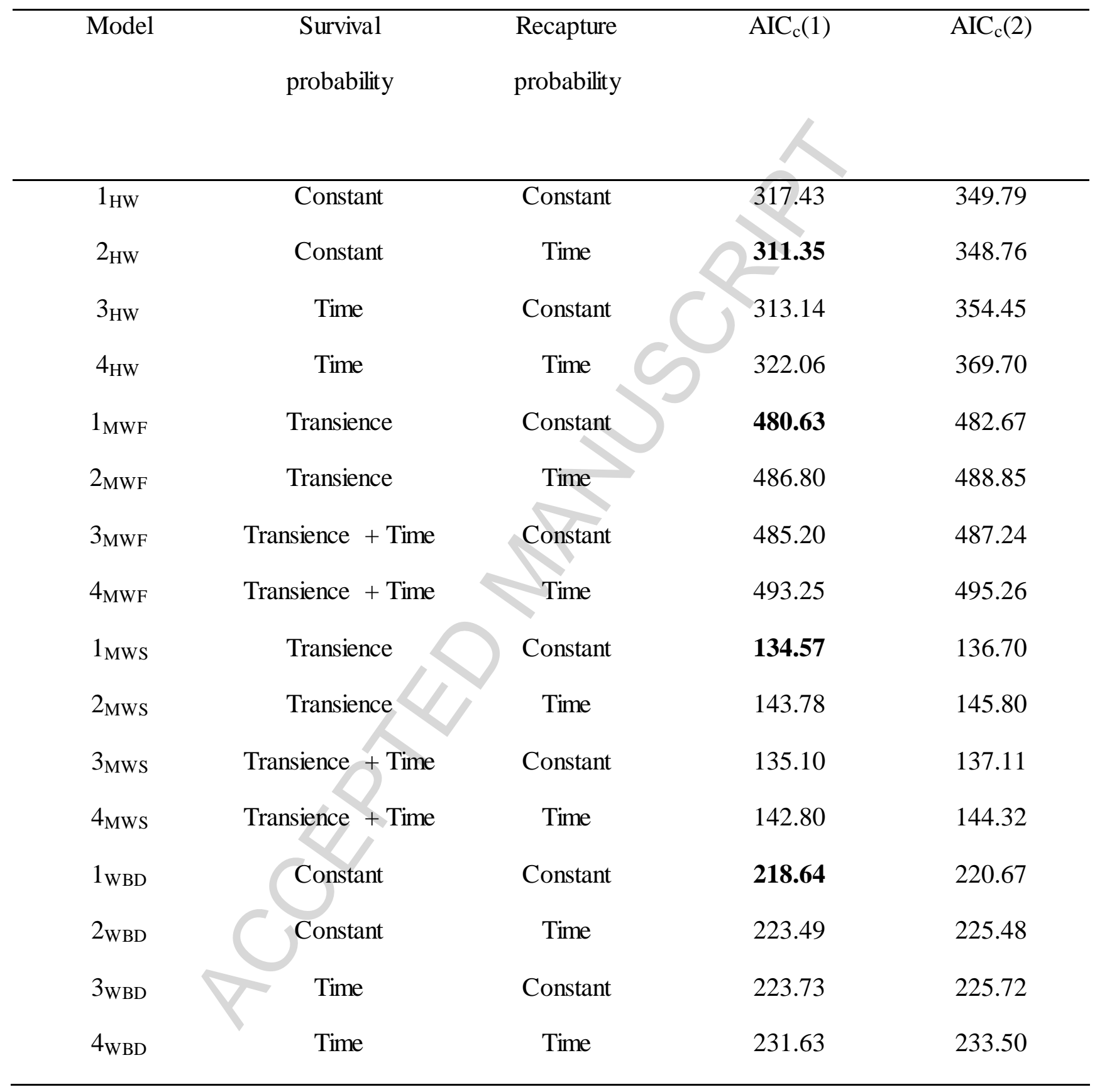




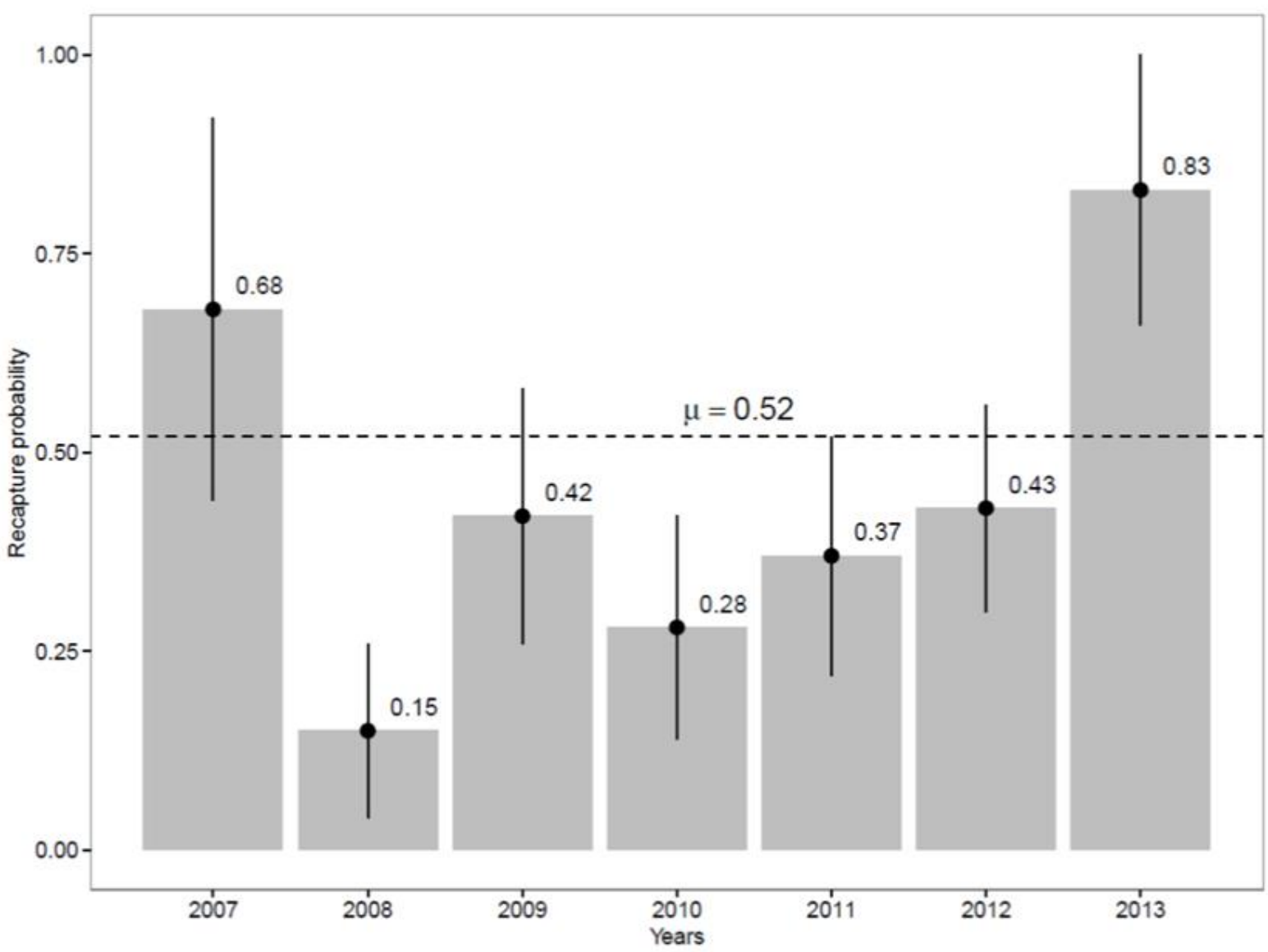

Figure 4. Recapture probability estimates for adult humpback whales in Skjálfandi, with 95\% confidence intervals (vertical bars). The black dashed line represents the average estimate of recapture probabilities $(\mu=$ average detection). 
a)
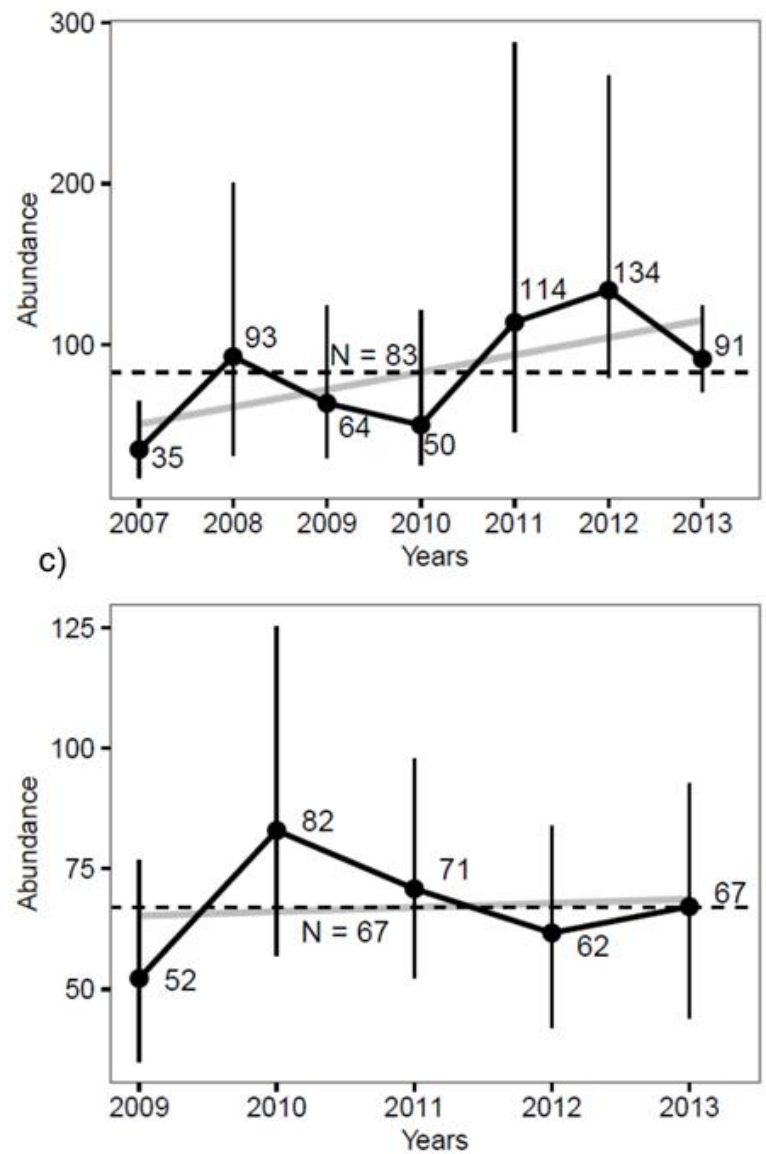

b)
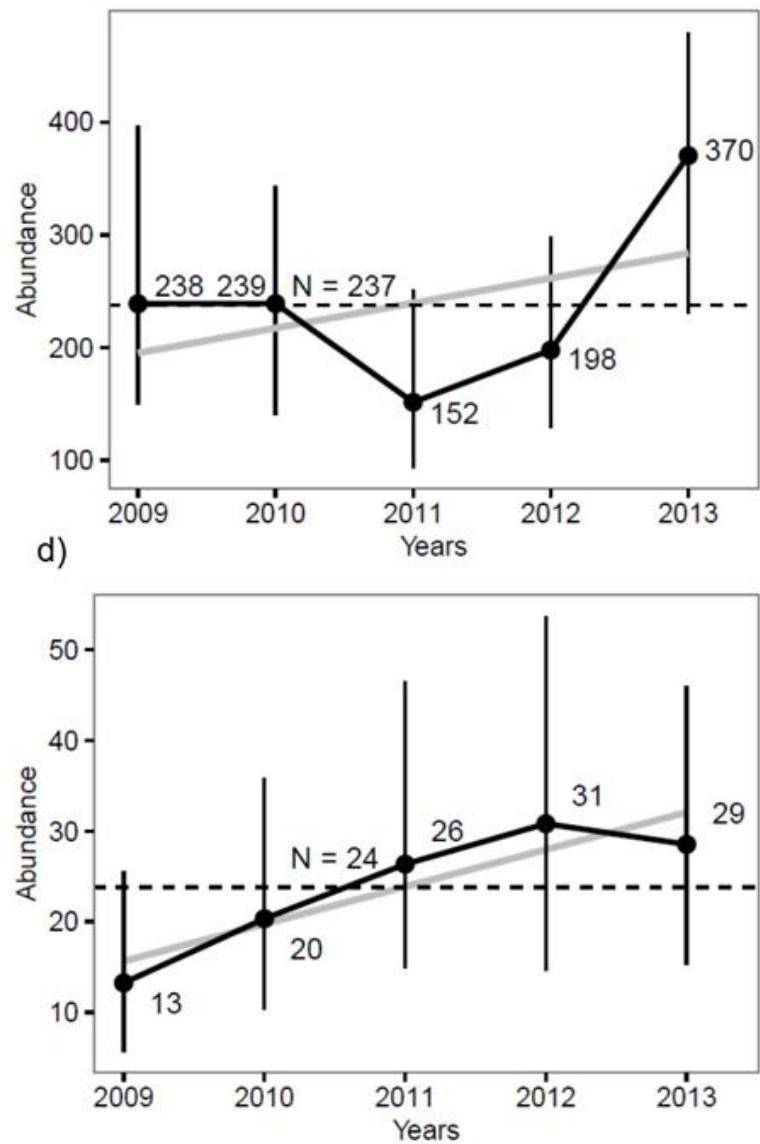

Figure 5. Abundance estimates of: a) humpback whales in Skjálfandi; (b) white-beaked dolphins in Faxaflói; c) minke whales in Faxaflói; d) minke whales in Skjálfandi. The grey line represents fitted regression of abundance over time.

\subsection{White-beaked dolphins}

A cumulative number of 216 individual adult white-beaked dolphins were photo-identified from 2008 to 2013 (Fig. 2) in Faxaflói, with 37\% (n=79) of individuals photographed more than once and 22\% $(n=48)$ photographed across multiple years. A total of 184 white-beaked dolphin groups were encountered. Photographs quality rated Q5 or higher of 216 individuals were taken for $41 \%(n=76)$ of these groups. A total of $20 \%(n=15)$ of these groups had $50 \%$ or more individuals identified within each group. The recapture frequencies of the 216 marked white-beaked dolphins ranged from 1 to 9 with a median of 1 recapture an interquartile range (IQR) between 1 and 2 (Fig. 3). Following Culloch (2004), 91\% of identified individuals were 'rare' $(\mathrm{n}=197)$, while $0.5 \%(\mathrm{n}=$ 
1) were 'common' to 'frequent, with no 'occasional' $(n=0)$. In Faxaflói, we found that the CJS model fitted the data well $\left(\chi^{2}=21.3\right.$, df $\left.=12, P=0.05\right)$. To account for possible lack of fit, we used a coefficient of overdispersion of 1.8 (calculated as the ratio between the value of the overall goodness-of-fit test statistic and the number of degrees of freedom, here 21.3/12). The best CJS model retained constant survival and recapture probabilities ( $1_{\mathrm{WBD}}$, Table 2 ). Models assuming homogeneity in the detection process were uniformly better supported than their heterogeneous counterpart (Table 2). The estimated constant survival was $0.79(0.64-0.88, \mathrm{SE}=0.04)$. A constant recapture probability was estimated at $0.20(0.13-0.28)$. On average, we estimated a total abundance of 237 white-beaked dolphins in Faxaflói (163-321). The annual abundance varied from 152 dolphins in 2011 (94-251) to 370 in 2013 (213-480, Fig. 5b). We did not find any significant trends in the abundance estimates.

\subsection{Minke whales}

\subsubsection{Faxaflói}

A cumulative number of 191 individual adult minke whales were photo-identified from 2008 to 2013 (Fig. 2) in Faxaflói, with 44\% ( $\mathrm{n}=85)$ of individuals photographed more than once and $31 \%(n=59)$ photographed across multiple years. A total of 2183 minke whale groups were encountered. Photographs quality rated Q5 or higher of 199 individuals were taken for $18 \%$ ( $\mathrm{n}=$ $385)$ of these groups. A total of $62 \%(n=237)$ of these groups had $50 \%$ or more individuals identified within each group. The recapture frequencies of the 191 marked minke whales ranged from 1 to 15 with a median of 1 recapture an interquartile range (IQR) between 1 and 3 (Fig. 3). Following Culloch (2004), 83\% of identified individuals were 'rare' $(\mathrm{n}=158), 5 \%(\mathrm{n}=10)$ were 'common' to 'frequent' and $12 \%$ were occasional $(\mathrm{n}=23)$. In Faxaflói Bay, transience was significant (TEST 3.SR, $\chi^{2}=16.04, \mathrm{df}=4, P<0.001$ ). Once a transient effect was accounted for, the CJS model fitted the data well $\left(\chi^{2}=5.3, \mathrm{df}=8, P=0.72\right)$. The best model retained a transient effect 
on survival probability and constant recapture probability (1 $1_{\mathrm{MWF}}$, Table 2$)$. Models assuming homogeneity in the detection process were uniformly better supported than their heterogeneous counterpart (Table 2). The average proportion of transients in the photo-identified minke whales was $45 \%(27 \%-60 \%)$. The survival was estimated at $0.80(0.68-0.88)$ for resident individuals. A constant recapture probability was estimated at $0.54(0.43-0.64, \mathrm{SE}=0.05)$. On average, we estimated a total abundance of 67 resident minke whales in Faxaflói Bay (53-82). The annual abundances varied from 52 whales in 2009 (35-77) to 82 whales in 2010 (57-125, Fig. 5c). No significant trend was found in abundance estimates and due to low detection rates.

\subsubsection{Skjálfandi}

A cumulative number of 38 individual adult minke whales were photo-identified from 2008 to 2013 (Fig. 2) in Skjálfandi, with $53 \%(\mathrm{n}=20)$ of individuals photographed more than once and $47 \%(\mathrm{n}=$ 18) photographed across multiple years. A total of 897 minke whale groups were encountered. Photographs quality rated Q5 or higher of 39 individuals were taken for $13 \%(\mathrm{n}=114)$ of these groups. A total of $84 \%(n=96)$ of these groups had $50 \%$ or more individuals identified within each group. The capture frequencies of the 38 marked minke whales ranged from 1 to 22 with a median of 2 recaptures an interquartile range (IQR) between 1 and 4 (Fig. 3). Following Culloch (2004), $71 \%$ of identified individuals were 'rare' $(\mathrm{n}=27), 18 \%(\mathrm{n}=7)$ were 'common' to 'frequent', and $10 \%$ were 'occasional' $(n=4)$. In Skjálfandi, transience was significant $\left(\right.$ TEST 3.SR, $\chi^{2}=17.0$, df $=$ 4, $P=0.002)$. Once a transient effect was incorporated, the CJS model fit the data well $\left(\chi^{2}=11.3, \mathrm{df}\right.$ $=7, P=0.13$ ). The best CJS model retained a transient effect on survival probability and constant recapture probability $\left(1_{\mathrm{MWS}}\right.$, Table 2$)$. Model $2\left(2_{\mathrm{MWS}}\right.$ : Survival probability = transience + time; recapture probability $=$ constant; $\left.\operatorname{AIC}_{\mathrm{c}}(1)=135.10\right)$ received a similar support to the best CJS model but based on our experience with transient models (e.g., Madon et al., 2013), we noticed that models including time variation on the transient parameter led to estimability issues in this 
parameter, hence a problem in estimating the abundance of the resident population. Therefore, we relied on the selected model to carry out biological inference.

Models assuming homogeneity in the detection process were uniformly better supported than their heterogeneous counterpart (Table 2). The average proportion of transients in the photoidentified minke whales was estimated $27 \%(0.1 \%-46 \%)$, with substantial uncertainty due to the low number of individuals in the dataset and imprecise survival estimates. The estimated survival for resident individuals was $0.96(0.42-0.86)$. A constant recapture probability was estimated equal to $0.56(0.40-0.71)$. On average, we estimated a total abundance of 24 minke whales in Skjálfandi (14-31). The annual abundance varied from 13 whales in 2009 (6-26) to 31 in 2012 (15-54, Fig. 5d). We detected a significant positive time trend in the abundance estimates (adjusted $\mathrm{r}^{2}=0.78, P$ $<0.001)$.

\section{Discussion}

Capture-recapture methods have been used in a small number of studies focusing on humpback whales, white-beaked dolphins and minke whales throughout the North Atlantic (Smith et al., 1999, Marques et al., 2012, Brereton et al., 2016). However these studies did not cover Icelandic waters or data collected on-board opportunistic vessels by trained scientist-volunteers. By using sighting and photographic data collected on board whale-watching boats with the help of scientist-trained volunteers we were able to use a platform, which was already involved in monitoring whales and dolphins in Icelandic coastal shelf waters, to train volunteers in identifying and collecting photo-ID images of local cetacean species. We were also able to produce abundance and survival estimates by balancing biases produced by a limited control over the areas a whalewatch boat covers, and the non-dedicated sampling methods used (Evans \& Hammond, 2004; Urian et al., 2015) and applied strict quality controls, rigorous selection and training effort. 


\subsection{Can data collected by trained-scientist volunteers onboard} opportunistic vessels be used to estimate cetacean abundance and survival?

\subsubsection{Capture-recapture issues}

The fifth assumption of equal survival probability could not be achieved in this study because of the minke whaling which was conducted in the Iceland continental shelf area between 1975 and 1985, and resumed again in 2003 until present. From 2008 to 2013, a total of 324 individuals were caught (Marine Research Institute, 2014) in different bays around Iceland, with the majority of catches made in Faxaflói. With these caught individuals been removed from these two populations our estimates are likely biased. In the future, we also recommend the use of CR models allowing the incorporation of cause-specific death (Koons et al., 2014) - i.e., taking whaling into account - to disentangle natural mortality from human-induced mortality.

A movement outside of our two study sites was recorded, making the assumption of equal capture probability partially met. Ryan et al. (2014) suggested temporary or permanent migration could result in biased survival estimates but because emigration and movement were not investigated in this study this hypothesis cannot be tested. Usually, in such situations, a robust design approach is adopted to account for temporary emigration (Pollock, 1982). The Pollock's closed robust design could be used in the future pending some modifications (e.g. covering each study area as a whole in every single secondary occasion) to the sampling protocol used in this study.

\subsubsection{Citizen Science issues}

Using volunteers to collect research data is widely adopted in marine science particularly with cetacean research. However, bias can be introduced in survey data results due to differences in the background and skills of each volunteer who partake in a research project (summarized in Thiel 
et al., 2014). In this study, a lot of effort and time was put into selecting candidates with a scientific background with prior experience in collecting photo-id images of whales and dolphins and with good photographic skills. Training on board was pivotal to produce data of quality with the least amount of bias to use for conservation purposes.

\subsubsection{Opportunistic platform issues}

Whale-watching vessels as well as other 'platforms of opportunity' are particularly appealing because they allow for research on a low budget, as well as to study species that are poorly known, highly mobile and difficult to sight regularly (Evans \& Hammond, 2004). However, limitations to the use of these vessels e.g. encounter duration dependent on the captain's decision to stay/leave the animals, pre-determined routes, species misidentification and uneven distribution of effort, need to be accounted for (summarized in Robbins \& Mattila, 2000). Limited chances to survey the whole extent of each study area during photo-id boat based tours onboard opportunistic vessels, and knowing that sampling area in this study is contained within a wider area (Pike et al., 2009) which is part of our three target species distributional area, a bias in survival and abundance estimates was introduced. Therefore, considering the pre-determined course of tours and limited duration of each encountered with cetacean species, abundance and survival estimates we produced in this study referred to the animals occurring within the effort area covered, not to the entire populations of humpback whales, white-beaked dolphins and minke whales occurring in Icelandic waters.

\subsection{How do our estimates of apparent survival compare with those of} humpback whale, white-beaked dolphin and minke whale found outside of

\section{Iceland?}

The estimated overall survival rate for humpback whales $(0.52,[0.41-0.63])$ in this study was similar to estimates of resident Southeastern Pacific humpback whales from Ecuador (Felix et 
al., 2011). In general, however, humpback whale survival estimates are much higher (Barlow \& Clapham, 1997). White-beaked dolphin survival rates in this study (0.79 [0.64-0.82]) were similar to common dolphins (Delphinus sp.) and Hector's dolphins (Cephalorhynchus hectori) in New Zealand (Slooten \& Dawson, 1992; Gormley et al., 2005; Hupman, 2016) and humpback dolphins (Sousa sp.) in the Darwin region, Australia (Brooks \& Pollock, 2014), but overall lower than most values reported in other dolphin species showing similar population characteristics to the one presented in this study (Silva et al., 2009). Survival estimates for resident minke whales in both bays (Faxaflói: 0.80 [0.68-0.88]; Skjálfandi: 0.96 [0.42-0.86]) are similar to reported minke whales (from Korea) and fin whale (from western Canada) survival estimates elsewhere (Ramp et al., 2006, 2014; Zhang et al., 2010). In this study, we estimated 'apparent' survival which is underestimated, when compared to the true survival. Future analyses could resort to recently developed methods to infer true survival, such as kernel models (Gilroy et al., 2012) or spatially-explicit CR models (Efford, 2004).

The low apparent survival rates recorded in humpback whales, white-beaked dolphins and minke whales are likely related to the open nature of all these populations with higher level of emigrations (temporary and permanent). In this study we estimated 'apparent' survival' (Lebreton et al., 1992) which is known to be underestimated compared to the true survival, unless permanent emigration equals zero. Similarities and differences between the survival estimates presented in this study and the one available in the literature could be also explained by the ecological features of the environment each species occupy (Currey et al., 2009). In a recent study conducted on killer whales (Orcinus orca) on the Pacific coast (Ward et al., 2011) the authors have found survival to change in response to change in prey abundance. The low survival estimates reported in this study might reflect the changes in abundance and distribution of many fish species in the Icelandic marine environment some of which (e.g. sandeel, capelin, euphasiids, gadoids) are known to be preferred prey species for our three cetacean species (Vikingsson \& Ólafsdóttir, 2004; Vikingsson et al., 2015). The lower survival rates for humpback whales and white-beaked dolphin could also be the 
result of the overlap of our study areas with boating activities. Skin marks caused by fishing activities and death have been reported in Iceland for all three species, but no laws or regulations exist to protect whales and dolphins from entanglement with gillnets within and outside of our study areas (reviewed in Basran, 2014). Whale-watching activities do not appear to affect adult minke whale survival in Faxaflói (Christiansen et al., 2015) but only preliminary studies have been conducted on humpback whales and white-beaked dolphins. Alternatively, Felix et al. (2011) argued that lower survival estimates might be caused by a 'transient effect', although transience in the present study has only been reported in minke whales. Lastly, according to findings in other locations outside of Iceland (Ramp et al, 2010), survival rates in whales and dolphins was suggested to be sex-dependent. Unfortunately, sex could not be reliably determined for the three cetacean species used in the analyses for this study so we are unable to say whether sex affected survivability in this case. Future studies assessing sex among whales and dolphins occurring in Icelandic coastal waters could also clarify if these differences explain the low survival values obtained in this study.

\subsection{What is the short term stability of the three populations?}

The 'discovery' curves of all three species rose steadily year after year without reaching a plateau, as shown by Figure 2. This could indicate an open population in both study areas as it has been suggested by sighting frequencies and movements inside and outside of each site. This rise could also suggest some effort is still needed to photo-identify all individuals occurring within the study area (e.g. Karczmarski et al., 1999), as the areas of Faxaflói and Skjálfandi surveyed during this study covers a portion of the entire bay.

A significant positive trend in abundance was detected for minke whales occurring in Skjálfandi. Historical data on minke whales from aerial surveys reported this species to be declining more dramatically since 2007 in southern and western waters (Borchers et al., 2009; Pike et al. 
2009, 2011; Vkikingsson et al., 2015) but to be increasing along the northeast shore (Stratum 4, Area $\left.>12,000 \mathrm{~nm}^{2}\right)$ with $1,743(951-3,194)$ in 1987 and 5,839 $(3,817-8,908)$ in 2001 (Borchers et al, 2009). While results from these two studies (aerial surveys and the present study) cannot be directly compared due to differences in methods of data collection, the positive trend in abundance could be mirroring the existing trend reported by Borchers et al (2009). For the humpback whale, the whitebeaked dolphins and the minke whales from Faxaflói (southwest coast) no real trend in abundance, a lack of statistical power or a displacement or new arrivals from other areas could explain why no significant positive trend in abundance was found.

We believe the abundance estimates obtained in this study do not carry an overestimation bias (Madon et al., 2012) since we corrected our population size estimates by the proportion of transients. However, we need to keep in mind that in this study we focus on two localities and do not consider the wider population present in Icelandic waters. A larger sample size and monitoring more geographical areas are also needed before drawing firm conclusions about residency vs. transience patterns in Icelandic waters. We would also like to stress the importance of using longer time series are needed to understand the conservation status and population trends of these species.

Abundances do not present signs suggesting that the conservation status of any of our three target species in our two study sites is of concern, since no negative trends in abundance were observed, although before drawing any firm conclusions bias and limitations of this study should be taken into account when interpreting our results. As it was suggested in other similar cases (Parra et al., 2006) the best approach would be to keep monitoring the conservation status of our target populations regardless of evidences of increment/decrement.

\subsection{Do these populations show any evidence of 'transience'?}

The results in this study showed that transience was present for minke whales in both Faxaflói and Skjálfandi. It has been suggested that transience could be a result of heterogeneity in the sampling effort (Madon et al., 2012). Table 1 shows lower sampling effort in the year 2009 for 
minke whales in Faxaflói. It is unlikely though that the observed transience was due to low sampling effort for $1 / 6$ of the years. The transient effect could also be sex-specific. A recent study demonstrated female humpback whales in New Caledonia are more prone to be transient than males during the breeding season, which was attributed to females' more elusive behaviour and shorter residency times (reviewed in Madon et al., 2012). An Icelandic study on segregation of sexes of minke whales based on catch data (Hauksson et al., 2013) showed that during the years of our study (2008-2013) more males than females were found along the southwest coast (including Faxaflói). Assessing the sex-ratio in minke whales in both our study sites and coastal areas where commercial whaling is not conducted, and their ranging patterns could provide more insight into the transiency we found in this species and help in providing more accurate demographic estimates for Iceland.

In our case, failing to detect transience for humpback whales and white-beaked dolphins could be due to a lack of statistical power, to its sex-related nature or reflect the effort spent sampling both our study areas. Future studies with a higher effort spent in multiple locations throughout the Icelandic coastline could reveal more about the transient nature of these local species.

\section{Conclusions}

We acknowledge that aerial surveys have provided large scale abundance estimates for the species in Icelandic coastal shelf waters. However, we also must acknowledge that due to high costs these surveys only can provide a snap shot of the populations several years apart. In Iceland, whalewatching platforms have been used from 1999 to collect data on humpback whales, white-beaked dolphins and minke whales by scientists and trained volunteers, establishing a base line of data spanning almost two decades. The local abundance and survival estimates produced in this paper represent a valid starting point to keep managing and conserving three species occurring in Icelandic coastal waters, especially in light of 1) the expansion of the whale-watching industry in Iceland, 2) the changes in abundance and distribution of local fish and cetacean species, and 3) the 
existing sources of disturbance the three cetacean populations face within our study areas and outside of them. However, in order for the abundance and survival estimates presented in this study to be useful for management and conservation decisions, it is pivotal to introduce modifications to the sampling methods used in order to minimize the existing bias. In the future, we recommend enlarging the sampling area, collecting data from more sites to collect a larger body of photo-id images to be able to look into emigration and movement that were not investigated in this study. We also suggest determining sex ratios which would allow future studies to produce estimates encompassing the entire population for each of these cetacean species and their regional conservation status.

\section{Author Contributions}

Conceived and designed the experiments: CGB LG OG. Performed the experiments: CGB LG OG. Analyzed the data: CGB LG NMcG AS NB TM OG. Contributed reagents/materials/analysis tools: MHR LG OG. Wrote the paper: CGB LG NMcG OG.

\section{Acknowledgements}

We thank Elding whale-watching and North Sailing for their support to the research on whales and dolphins throughout the years and for providing vessels to collect data from. Immense gratitude goes to all Faxaflói Cetacean Research volunteers who conducted fieldwork from 2007 to 2013 in Faxaflói and Skjálfandi. Thanks are also due to the volunteers from the Húsavik Whale Museum and the Húsavik Research Center. Thanks to David J. Janiger for making several papers available. 


\section{References}

Alves, F., Dinis, A., Nicolau, C., Ribeiro, C., Kaufmann, M., Fortuna, C., Freitas, L., 2014. Survival and abundance of short-finned pilot whales in the archipelago of Madeira, NE Atlantic. Mar. Mamm. Sci. 31, 106-121.

Barlow, J., Clapham, P.J., 1997. A new birth-interval approach to estimating demographic parameters of humpback whales. Ecol. 78, 535-546.

Basran, C., 2014. Scar-based analysis and eyewitness accounts of entanglement of humpback whales (Megaptera novaeangliae) in fishing gear in Iceland. MSc thesis. The University of the Westfjords, Ísafjörður, Iceland.

Bertulli, C.G., Cecchetti, A., Van Bressem, M.-F., Van Waerebeek, K., 2012. Skin disorders in common minke whales and white-beaked dolphins off Iceland, a photographic assessment. 5(2), 29-40.

Bertulli, C.G., Rasmussen, M.H., Tetley, M.J., 2013. Photo-identification rate and wide-scale movement of common minke whales (Balaenoptera acutorostrata) in the coastal waters of Faxaflói and Skjálfandi Bays, Iceland. J. Cetacean Res. Manage. 13, 39-45.

Bertulli, C.G., Tetley, M.J., Magnúsdóttir, E.E., Rasmussen, M.H., 2015. Observations of movement and site fidelity of white-beaked dolphins (Lagenorhynchus albirostris) in Icelandic coastal waters using photo-identification. J. Cetacean Res. Manage. 15, 27-34.

Bertulli, C.G., Rasmussen, M.H., Rosso, M., 2016. An assessment of the natural marking patterns used for photo-identification of common minke whales and white-beaked dolphins in Icelandic waters. J. Mar. Biol. Ass. U. K. 96(4), 807-819.

Borchers, D., Pike, D., Gunnlaugsson, H., Vikingsson, G., 2009. Minke whale abundance estimation from the NASS 1987 and 2001 aerial cuecounting surveys taking appropriate account of distance estimation errors. NAMMCO Sci. Publ. 7, 95-110. 
Brereton, T., Kitching, M. Davies, R., McKnie, F., Walker, R., 2016. Photo-identification Analysis of White-beaked Dolphins off South west and North east England 2007-2014. Available at: http://publications.naturalengland.org.uk/public ation/5149990171705344.

Bristow T., Glanville, N., Hopkins, J., 2001. Shore-based monitoring of bottlenose dolphins (Tursiops truncatus) by trained volunteers in Cardigan Bay, Wales. Aquat. Mamm. 27(2), 115-120.

Brooks, L., Pollock, K., 2014. Abundance, movements and habitat use of coastal dolphins in the Darwin region: Analysis of the first five primary samples (October 2011 to October 2013). Final report to the Northern Territory Government Department of Land Resource Management.

Bruce, E., Albright, L., Sheehan, S., Blewitt, M., 2014. Distribution patterns of migrating humpback whales (Megaptera novaeangliae) in Jervis Bay, Australia: A spatial analysis using geographical citizen science data. Appl. Geogr. 54, 83-95.

Burnham, K.P., Anderson, D.R., 2002. Model Selection and Multimodel Inference: a practical information-theoretic approach, 2nd edition. Springer, New York, USA.

Choquet, R., Lebreton, J.D., Gimenez, O., Reboulet, A.M., Pradel, R., 2009. U-CARE: Utilities for performing goodness of fit tests and manipulating Capture-Recapture data. Ecography 32, 1071-1074.

Christiansen, F., Bertulli, C.G., Rasmussen, M.H., Lusseau, D., 2015. Estimating cumulative exposure of wildlife to non-lethal disturbance using spatially explicit capture-recapture models. J. Wildlife Manage. 79, 311-324.

Cubaynes, S., Pradel, R., Choquet, R., Duchamp, C., Gaillard, J.-M., Lebreton, J-D., Marboutin, E., Miquel, C., Reboulet, A-M., Poillot, C., Taberlet, P., Gimenez, O., 2010. Importance of accounting for detection heterogeneity when estimating abundance: the case of French wolves. Conserv. Biol. 24, 621-626. 
Culloch, R.M., 2004. Mark recapture abundance estimates and distribution of bottlenose dolphins (Tursiops truncatus) using the southern coastline of the outer Moray Firth, NE Scotland. MSc thesis. The University of Wales, Bangor, Wales.

Currey, R.J.C., Dawson, S.M., Slooten, E., Schneider, K., Lusseau, D., Boisseau, O.J., 2009. Survival rates for a declining population of bottlenose dolphins in Doubtful Sound, New Zealand: An information theoretic approach to assessing the role of human impacts. Aquat Conserv 19, 658-670.

Dick, D.M., Hines, E.M., 2011. Using distance sampling techniques to estimate bottlenose dolphin (Tursiops truncatus) abundance at Turneffe Atoll, Belize. Mar. Mamm. Sci. 27(3), 606621.

Efford, M.G., 2004. Density estimation in live-trapping studies. Oikos 106:598-610.

Evans, P.H.G., Hammond, P.S., 2004. Monitoring cetaceans in European waters. Mammal Rev. 34(1), 131-156.

Felix, F., Castro, C., Laake, J.L., Haase, B., Scheidat, M., 2011. Abundance and survival estimates of the southeastern Pacific humpback whale stock from 1991-2006 photo-identification surveys in Ecuador. J. Cetacean Res. Manage. (Spec Issue) 3, 301-307.

Gilroy, J.J., Virzi, T., Boulton, R.L., Lockwood, J.L., 2012. A new approach to the 'apparent survival' problem: Estimating true survival rates from mark-recapture studies. Ecol. 93, $1509-1516$.

Gowans, S., Whitehead, H., 2001. Photographic identification of northern bottlenose whales (Hyperoodon ampullatus): sources of heterogeneity from natural marks. Mar. Mamm. Sci. $17,76-93$.

Gormley, A.M., Dawson, S.M., Slooten, E., Bräger, S., 2005. Capture recapture estimates of Hector's dolphin abundance at Banks Peninsula, New Zealand. Mar. Mamm. Sci. 21, 204-216. 
Gunnlaugsson, T., Sigurjónsson, J., Donovan, G.P., 1988. Aerial survey of Cetaceans in the coastal waters off Iceland, June-July 1986. Rep. Int. Whal. Commn. 38, 489-500.

Hammond, P.S. 1986. Estimating the size of naturally marked whale populations using capturerecapture techniques. Rep. int. Whal. Commn. (special issue) 8, 253-82.

Hauksson, E., Víkingsson, G.A., Sigurjónsson, J., 2013. Geographic, temporal and size segregation of sexes of the common minke whale (Balaenoptera acutorostrata) in Icelandic waters based on catch data from 1974 to 2009. Unpublished report. Int. Whal. Commn. SC/F13/SP14.

Higby, L.K., Stafford, R., Bertulli, C.G., 2012. An evaluation of ad hoc presence-only data in explaining patterns of distribution: cetacean sightings from whale-watching vessels. Int. J. Zool. Article ID 428752, doi:10.1155/2012/428752.

Hupman, K., 2016. Photo-identification and its application to gregarious delphinids: Common dolphins (Delphinus sp.) in the Hauraki Gulf, New Zealand. Ph.D thesis. Massey University, Albany, New Zealand.

Karczmarski, L., Winter, P.E.D., Cockcroft, V.G., McLachlan, A., 1999. Population analyses of Indo-Pacific humpback dolphins (Sousa chinensis) in Algoa Bay, Eastern Cape, South Africa. Mar. Mammal Sci. 15(4), 1115-23.

Katona, S., Baxter, B., Brazier, O., Kraus, S., Perkins, J., Whitehead, H., 1979. Identification of humpback whales by fluke photographs. In: Winn, H.E., Olla, B.L., eds. Behaviour of marine animals Volume 3, Plenum Press, New York, USA, pp. 33-44.

Kaufman, G., Maldini, D., Ward, B., Merrill, P., Moore, B., Kaufman, M., 2011. Enhancing Platforms of Opportunity Data Collection Using Newly Developed Whale \& Dolphin Tracker Software. Report of the Int. Whal. Commn 63, 1-12.

Koons, D.N., Gamelon, M., Gaillard, J.M., Aubry, L.M., Rockwell, P.F., Klein, F., Choquet, R., Gimenez, O., 2014. Methods for studying cause-specific senescence in the wild. Methods Ecol. Evol. 5, 924-933. 
Laake, J.L., 2013. RMark: An R Interface for Analysis of Capture-Recapture Data with MARK. AFSC Processed Report 2013-01. Alaska Fish. Sci. Cent. NOAA, Natl. Mar. Fish. Serv., 7600 Sand Point Way NE, Seattle WA 98115.

Lebreton, J.D., Burnham, K.P., Clobert, J., Anderson, D.R., 1992. Modelling survival and testing biological hypotheses using marked animals: a unified approach with case studies. Ecol. Monogr. 62, 67-118.

Lebreton, J-D., Nichols, J.D., Barker, R.J., Pradel, R., Spendelow, J.A., 2009. Modeling Individual Animal Histories with Multistate Capture-Recapture Models. In: Caswell, H., ed. Advances in Ecological Research, Vol. 41, Burlington: Academic Press, pp. 87-173.

Madon, B., Garrigue, C., Pradel, R., Gimenez, O., 2012. Transience in the humpback whale population of New Caledonia and implications for abundance estimation. Mar. Mamm. Sci. $29,669-678$.

Magnúsdóttir, E.E., Rasmussen, M.H., Lammers, M.O., Svavarsson, J., 2014. Humpback whale songs during winter in subarctic waters. Polar Biol. 37, 427-433.

Marine Research Institute., 2014. State of Marine Stocks in Icelandic Waters 2013/2014 - Prospects for the Quota Year 2014/2015. Unpublished report. Marine Research Institute, Reykjavik, Iceland.

Marques, T.A., Thomas, L., Martin S.W., Mellinger, D.K., Jarvis, S., Morrisey, R.P., Ciminello, CA., DiMarzio, N., 2012. Spatially explicit capture recapture methods to estimate minke whale density from data collected at bottom mounted hydrophones. J. Ornithol. 152, 445455 .

New, L.F., Hall, A.J., Harcout, R., Kaufman, R., Parsons, E.C.M., Pearson, H.C., Cosentino, M., Schick, R.S., 2015. The modelling and assessment of whale-watching impacts. Ocean Coast. Manage. 115, 10-16. 
Newman, C., Buesching, C.D., Macdonald, D.W., 2003. Validating mammal monitoring methods and assessing the performance of volunteers in wildlife conservation- 'Sed quis custodiet ipsos custodies'? Biol. Conserv. 113, 189-197.

Papale, E., Ceraulo, M., Giardino, G., Buffa, G., Feliciotto, F., Grammauta, R., Maccarone, V., Mazzola, S., Buscaino, G., 2016. Association patterns and population dynamics of bottlenose dolphins in the Strait of Sicily (Central Mediterranean Sea): implication for management. Popul. Ecol. 59(1), 55-64.

Parra, G.J., Corkeron, P.J., Marsh, H., 2006. Population sizes, site fidelity and residence patterns of Australian snubfin and Indo-Pacific humpback dolphins: implications for conservation. Biol. Conserv. 129, 167-180.

Pike, D.G., Paxton, C.G.M., Gunnlaugsson, T. \& Vikingsson, G.A., 2009. Trends in the distribution and abundance of cetaceans from aerial surveys in Icelandic coastal waters, 1986-2001. NAMMCO Sci. Publ. 7, 117-42.

Pike, D.G., Gunlaugsson, T., Elvarsson, B., Vikingsson, G., 2011. Correcting perception bias for Icelandic aerial surveys, 2007 and 2009. Unpublished report. NAMMCO, SC/18/AESP/08.

Pledger, S., Pollock, K.H., Norris, J.L., 2010. Open Capture-Recapture Models with Heterogeneity: II. Jolly-Seber Model. Biometrics 66, 883-890.

Pollock, K.H., 1982. A capture-recapture design robust to unequal probability of capture. J. Wildlife Manage. 46, 752-757.

Pradel, R., Hines, J.E., Lebreton, J-D., Nichols, JD., 1997. Capture-recapture survival models taking account of transients. Biometrics 53, 60-72.

Pradel, R., Gimenez, O., Lebreton, J-D., 2005. Principles and interest of GOF tests for multistate capture-recapture models. Anim. Biodiv. Conserv. 28, 189-204.

Ramp, C., Bérubé, M., Hagen, W., Sears, R., 2006. Survival of adult blue whales Balaenoptera musculus in the Gulf of St. Lawrence, Canada. Mar. Ecol. Progr. Ser. 319, 287-295. 
Ramp, C., Bérubé, M., Palsbøll, P., Hagen, W., Sears, R., 2010. Sex-specific survival in the humpback whale Megaptera novaeangliae in the Gulf of St. Lawrence, Canada. Mar. Ecol. Progr. Ser. 400, 267-276.

Robbins, J., Mattila, D.K., 2000. The use of commercial whale-watching platforms in the study of cetaceans: benefits and limitations. Unpublished report. Scientific Committee Int. Whal. Commn., Adelaide, Australia.

Rosso, M., Ballardini, M., Moulins, A., Würtz, M., 2011. Natural markings of Cuvier's beaked whale Ziphius cavirostris in the Mediterranean Sea. Afr. J. Marine Sci. 33, 45-57.

Ryan, C., Wenzel, F.W., López Suárez, P., Berrow, S.D., 2014. An abundance estimate for humpback whales Megaptera novaeangliae breeding around Boa Vista, Cape Verde Islands. Zool. Caboverdiana 5, 20-28.

Santostasi, N.L., Bonizzoni, S., Bearzi, G., Eddy, L., Gimenez, O., 2016. Robust design capturerecapture analysis of abundance, survival and temporary emigration of three odontocete species in the Gulf of Corinth, Greece. PLoS ONE 11(12), e0166650. doi:10.1371/journal.pone.0166650.

Silva, M.A., Magalhaes, S., Prieto, R., Santos, R.S., Hammond, P.S., 2009. Estimating survival and abundance in a bottlenose dolphin population taking into account transience and temporary emigration. Mar. Ecol. Progr. Ser. 392, 263-276.

Silvertown, J., 2009. A new dawn for citizen science. Trends Ecol. Evol. 24, 467-471.

Slooten, E., Dawson, S.M., 1992. Survival rates of photographically identified Hector's dolphins from 1984 to 1988. Mar. Mamm. Sci. 8, 327-343.

Smith, T.D., Allen, J., Clapham, P.J., Hammond, P., Katona, S.K., Larsen, F., Lien, J., Mattila, D., Palsbøll, P.J., Sigurjónsson, J., Stevick, P.T., Øien, N., 1999. An ocean-basin-wide markrecapture study of the North Atlantic humpback whale (Megaptera novaeangliae). Mar. Mamm. Sci. 15, 1-32. 
Thiel, M., Penna-Diaz, A., Luna-Jorquera, G., Salas, S., Sellanes, J., Stotz, W., 2014. Citizen scientists and marine research: volunteer participants, their contributions and projection for the future. Oceanogr. Mar. Biol.: An Annual Review 52, 257-314.

Urian, K., Gorgone, A., Read, A., Balmer, B., Wells, R.S., Berggren, P., Durban, J., Eguchi, T., Rayment, W., Hammond, P., 2015. Recommendations for photo-identification methods used in capture-recapture models with cetaceans. Mar. Mamm. Sci. 31(1), 298-321.

Vikingsson, G.A., 2004a. Hrefna (Common minke whale). In: P. Hersteinsson, ed. Mammals, Vaka-Helgafell, Reykjavik, Iceland, pp. 218-223. [In Icelandic].

Vikingsson, G.A., 2004b. Hnúfubakur (Humpback whale). In: P. Hersteinsson, ed. Mammals, Vaka-Helgafell, Reykjavik, Iceland, pp. 224-229. [In Icelandic].

Vkikingsson, G.A., Ólafsdóttir, D., 2004. Hnýðingur (White-beaked dolphin). In: P. Hersteinsson, ed. Mammals, Vaka-Helgafell, Reykjavik, Iceland, pp. 154-157. [In Icelandic].

Vikingsson, G.A., Pike, D.G., Valdimarsson, H., Schleimer, A., Gunnlaugsson, T., Silva, T., Elvarsson, B.P., Mikkelsen, B., Øien, N., Desportes, G., Bogason, V., Hammond, P., 2015. Distribution, abundance, and feeding ecology of baleen whales in Icelandic waters: have recent environmental changes had an effect? Frontiers Ecol. Evol. 3, 1-18.

Ward, E.J., Semmens, B.E., Holmes, E.E., Balcolm III, K.C., 2011. Effects of multiple levels of social organization on survival and abundance. Conserv. Biol. 25, 350-355.

Williams, K.B., Nichols, D.J., Conroy, J.M., 2002. Introduction to Population ecology. Analysis and Management of Animal Populations. San Diego, CA: Academic Press. pp. 3-9.

Würsig, B., Würsig, M., 1977. The photographic determination of group size, composition and stability of coastal porpoises, Tursiops truncatus. Science 198, 755-756.

Zaeschmar, J.R., Visser, .I.N., Fertl, D., Dwyer, S.L., Meissner, A.M., Halladay, J., Berghan, J., Donnelly, D., Stockin, K.A., 2014. Occurrence of false killer whales (Pseudorca crassidens) and their association with common bottlenose dolphins (Tursiops truncatus) off northeastern New Zealand. Mar. Mamm. Sci. 30, 594-608. 
Zhang, C.I., Song, K-J., Na, J-H., 2010. Estimation of mortality coefficients and survivorship curves for minke whales (Balaenoptera acutorostrata) in Korean waters. Anim. Cells Syst. 14(4), 291-296.

\section{Figures}

Figure 1. Map of the study area showing Faxaflói (b) and Skjálfandi (c), Iceland. Sub-panels show the density of observations made within the two areas; surveys were conducted within light grey areas.

Figure 2. Summary of discovery curves (cumulative number of newly identified and catalogued whales and dolphins each year) of marked adult (a) humpback whales from Skjálfandi (continuous line with empty circles), (b) white-beaked dolphins from Faxaflói (dotted line with full circles) and (c) minke whales from both bays (dotted line with empty triangles for Faxaflói; dashed line with full squared for Skjálfandi), in each year (2006-2013).

Figure 3. Distribution of capture frequencies of all identified (i) humpback whales in Skjálfandi (dark grey), (ii) white-beaked dolphins in Faxaflói (light grey), (iii) minke whales in Faxaflói (white), and (iv) Skjálfandi (black).

Figure 4. Recapture probability estimates for adult humpback whales in Skjálfandi, with 95\% confidence intervals (vertical bars). The black dashed line represents the average estimate of recapture probabilities $(\mu=$ average detection).

Figure 5. Abundance estimates of: a) humpback whales in Skjálfandi; (b) white-beaked dolphins in Faxaflói; c) minke whales in Faxaflói; d) minke whales in Skjálfandi. The grey line represents fitted regression of abundance over time. 


\section{Tables}

Table 1. Annual effort spent for each species $(\mathrm{MW}=$ minke whale, $\mathrm{WBD}=$ white-beaked dolphin, HW = humpback whale $)$ in each site $(\mathrm{F}=$ Faxaflói, $\mathrm{S}=$ Skjálfandi) from 2008 (2006 for humpback whale) to 2013.

Table 2. AICc scores for the four models (1-4) for each species. $\mathrm{AIC}_{\mathrm{c}}(1)$ without heterogeneity, $\mathrm{AIC}_{\mathrm{c}}(2)$ with heterogeneity. $\mathrm{HW}=$ humpback whale, $\mathrm{MF}=$ minke whale, Faxaflói, $\mathrm{MS}=$ minke whale, Skjálfandi, WBD = white-beaked dolphin. The best model for each species is in bold font. 


\section{Highlights}

- Information is lacking on the abundance and survival of three cetacean species

- Scientist-trained volunteers collected data from onboard opportunistic platforms

- Open capture-recapture models were used taking transience into account

- Analysis showed small abundances, and low survival estimates

- Estimates are pivotal to manage and conserve Icelandic cetacean species 